\title{
Flowering and Seed Development in Onion-A Review
}

\author{
Khalid Mahmud Khokhar \\ Vegetable Crops Research Programme, Horticulture Research Institute, National Agricultural Research Centre, \\ Islamabad, Pakistan \\ Email: Tokmahmud@yahoo.com
}

Received 4 August 2014; revised 25 September 2014; accepted 26 October 2014

Copyright (C) 2014 by author and OALib.

This work is licensed under the Creative Commons Attribution International License (CC BY).

http://creativecommons.org/licenses/by/4.0/

(C) (i) Open Access

\begin{abstract}
Proper vernalization temperature of mother onion bulbs stimulates early flowering and produces a heavier yield of seed. Moreover, onion cultivars seem to differ in their optimal temperature requirements depending on the locality to which they are adapted. Most studies on the effects of storage temperature on inflorescence initiation in onion have shown that the optimum temperature for flowering is in a range between $5^{\circ} \mathrm{C}$ to $13^{\circ} \mathrm{C}$ for 90 to 120 days and bolting resistant varieties require a longer cold stimulus (154 - 185 days) in comparison to normal spring sown cultivars. Flowering is greatly reduced or suppressed at temperatures in the range of $15.5^{\circ} \mathrm{C}-30^{\circ} \mathrm{C}$ and low temperatures of $-3^{\circ} \mathrm{C}$ to $0^{\circ} \mathrm{C}$. Studies on both bulbs and seedlings have shown that, depending on genotype, flower initiation starts only after a juvenile phase, when the plant has a minimum number of 4 - 14 leaves, including leaf initials. The initiation of inflorescence is favoured by a large set or bulb size. The post planting environmental conditions greatly affect bolting percentage of bulbs stored at an inductive temperature. Maximum seed yield in onion has been reported from large mother bulbs and early planting time. The emergence of inflorescence is faster at high temperatures $\left(20^{\circ} \mathrm{C}-30^{\circ} \mathrm{C}\right)$ and long days $(14-16$ hours $)$.
\end{abstract}

\section{Keywords}

Onion, Inflorescence Initiation, Photoperiod, Temperature, Flowering and Seed Development

Subject Areas: Agricultural Science, Plant Science

\section{Introduction}

The cultivated onion (Allium cepa L.) is grown under a wide range of climates from temperate to tropical. It is the most important member of the family Alliaceae with monocotyledonous and cross pollinated behavior. It has diploid chromosome number $(2 \mathrm{n}=16)$ [1]. At least 175 countries grow onions. Onion is an important crop in all 
continents with world production of about 82 million metric tonnes during 2012 [2]. Seed production is a vital part in onion growing and is a highly specialized business requiring particular knowledge.

\section{Factors Controlling Inflorescence Initiation and Seed Stalk Development}

Flowering is an essential prerequisite of seed production. The production of onion seed has long been, and will continue to be, a highly-specialized industry. The seed yield in onion depends on a number of factors which include vernalization, physiological age, environmental factors, bulb/set size and post-planting conditions, and type of cultivar. Quality seed yield of onion depends on genotype, locality, season, method of seed production and adequate plant protection measures [3]-[9]. Among these, the physiological age of the plant as well as temperature and photoperiod has shown to exert the most important role.

\subsection{Vernalization}

Lack of cool weather conditions to induce flowering is the main constraint of onion seed production in many tropical countries. As a result, many countries have to import onion seed from sub-tropics or temperate countries where the winter season provides the chilling requirement for flowering [6]. Flowering in many plant species is regulated by environmental cues such as night length in photoperiodic flowering and temperature in vernalization [10]. Vernalization is the artificial exposure of plants (or seeds) to low temperatures in order to stimulate flowering or to enhance seed production. Proper vernalization temperature of mother bulb stimulates early flowering and produces a heavier yield of seed [11]. The vernalization requirement of onion plants for satisfactory flower initiation varies with cultivar. Cold temperatures between $5^{\circ} \mathrm{C}-13^{\circ} \mathrm{C}$ for 20 to 120 days were optimum for flower induction in most cultivars. However, bolting resistant varieties required a longer cold stimulus (154 185 days) in comparison to normal spring sown cultivars [6] [12]-[18]. It has been shown that relative rate of vernalization increases with increasing bulb weight [19]. As a result inflorescence primordia in larger bulbs are in a more advanced stage than those of small bulbs at the time of planting, resulting in earlier inflorescence emergence (early bolting) and floret opening. Studies were made to explore the possibility of producing onion seed using artificial vernalization and vernalization under natural conditions at high altitude in Kenya [20]. Bulbs were stored for 8 weeks in a cold room $\left(5^{\circ} \mathrm{C}\right.$ or $\left.10^{\circ} \mathrm{C}\right)$, in a well-ventilated storage room at high altitude (2530 m.a.s.l, average temperature $13.4^{\circ} \mathrm{C}$ ) or at room temperature at a lower altitude (1820 m.a.s.l, average temperature $21.9^{\circ} \mathrm{C}$ ). Bulbs stored at $10^{\circ} \mathrm{C}$ had the highest seed yield, followed by bulbs stored at $13.4^{\circ} \mathrm{C}, 5^{\circ} \mathrm{C}$ and $21.9^{\circ} \mathrm{C}$, for all cultivars except "Bombay Red" which produced higher seed yields at $21.9^{\circ} \mathrm{C}$ than at $5^{\circ} \mathrm{C}$. The results showed that commercial seed yields could be achieved by vernalizing bulbs at high altitude locations and thereafter planting for production at low altitudes in the tropics. Floral buds were formed in the plants exposed to $9^{\circ} \mathrm{C}$ for 20 to 30 days and, when exposed to a temperature lower or higher than $9^{\circ} \mathrm{C}$, more days of exposure were required for flower bud formation [12] and at temperatures lower than $9^{\circ} \mathrm{C}$, plants failed to form flower buds even after 70 days exposure. After 15 days of cold treatment at $7^{\circ} \mathrm{C}$ to $8^{\circ} \mathrm{C}$, none of the onions flowered and most cultivars responded to a cold treatment duration of 90 days [21]. Moreover, cold treatment for 45 - 60 days at $7^{\circ} \mathrm{C}-11^{\circ} \mathrm{C}$ induced flowering in some cultivars. In an extensive literature review, it was concluded that 3 months at $10^{\circ} \mathrm{C}$ was sufficient to fully induce flowering in almost any cultivar [6]. High temperatures following floral initiation can promote reversion from a floral to a vegetative condition, i.e., devernalization [22]-[25] which appears later as abnormal seed stalks with fewer seed-bearing florets per umbel, resulting in smaller seed yield. Inflorescences in most of the cultivars initiated at $11^{\circ} \mathrm{C}-13^{\circ} \mathrm{C}$ after 154 to 184 days, except in cv. "Rijnsburger Balstora", where initiation took place at $11^{\circ} \mathrm{C}$ to $18.9^{\circ} \mathrm{C}$ after 162 to 185 days [18]. Time of flowering may be influenced by the temperature used for cold storage, and also by date of planting [3] [9] [11] [26]-[31]. Storage temperatures between $0^{\circ} \mathrm{C}-12^{\circ} \mathrm{C}$ and early planting lead to earlier flowering [11] [31]. Percent flowering plant was significantly increased with the durational increase in cold treatment at $5^{\circ} \mathrm{C}$ [32]. Earlier and higher flowering have also been reported for vernalized bulb planting [33]-[35]. Maximum seeds per umbel and highest seed yield were produced by the plants when bulbs were vernalized at $5{ }^{\circ} \mathrm{C}$ [32]. Vernalization of onion bulbs at $5^{\circ} \mathrm{C}$ for 35 and 45 days contributed to an increase of seed yield [36] and the longer the treatment period, the higher the percentage of umbels which contributed to higher seed yield.

\subsection{Physiological Age}

Onions vary greatly in their floral initiation response to temperature, which can be attributed to differences in 
their genetical background [18] [19] [37] and to differences in their physiological age (seedling or bulb size) [9] [38] [39] at the time of induction. Onions are induced to flower by low temperatures provided they have passed the end of the juvenile phase [4] [22] [40]-[44]. Studies on both bulbs and seedlings have shown that, depending on genotype, flower initiation starts only after a juvenile phase, when the plant has a minimum number of 4 - 14 leaves, including leaf initials [4] [11] [22] [41]-[46]. Since leaf initiation rate is constant in a given environment for onion cultivars, the leaf number rather than chronological time is the best indicator of the plant's physiological age [4].

Criteria such as "sheath diameter" [42] [44] and "critical dry weight" of growing seedling, at which the plants are capable of flower initiation [19] [47], size of the bulb [38] [48] [49] and bulb weight [13] are also commonly used as measures of the end of the juvenile period. A minimum sheath diameter of between 3.3 and $6 \mathrm{~mm}$ is required before flower initiation can take place [42] and the larger the sheath diameter the shorter the period of low temperature $\left(9^{\circ} \mathrm{C}\right)$ exposure required for flower bud formation. In "Senshuki" (autumn sown variety), the critical sheath diameter seemed to be $6 \mathrm{~mm}$, while in "Sapporoki" (spring sown variety), the critical diameter was about $3 \mathrm{~mm}$ [42]. However, a minimum sheath diameter was observed between 13 and $13.8 \mathrm{~mm}$ for cvs. "Stuttgarter" and "Sturon", respectively, at floral initiation [44].

\section{Environmental Factors}

\subsection{Temperature}

Temperature is the most significant environmental factor controlling differentiation of the vegetative apex into the reproductive one [45] [50]. A large number of investigations have dealt with the effect of storage temperatures on sets and bulbs, and the subsequent blooming response [22] [24] [27] [28] [31] [38] [40] [45] [50]-[63]. Most studies on the effects of temperature on inflorescence initiation in onion have shown that the optimum temperature for flowering is in a range between $5^{\circ} \mathrm{C}$ to $13^{\circ} \mathrm{C}$ [11] [19] [21] [23] [24] [30] [31] [38] [40] [51] [52] [57] [64]. The temperature at which onion bulbs are stored influences the time required for the plants to flower. Storage temperature from $7^{\circ} \mathrm{C}$ to $12^{\circ} \mathrm{C}$ has been shown [40] [52] to induce earlier flowering than lower or higher temperature. The most effective temperature for promoting the initiation of inflorescence primordia was $9^{\circ} \mathrm{C}-13^{\circ} \mathrm{C}$ [23]. At a storage temperature of $3^{\circ} \mathrm{C}-5^{\circ} \mathrm{C}$, inflorescence initiation took place $1.5-2$ months later than at $9^{\circ} \mathrm{C}$ $13^{\circ} \mathrm{C}$ whereas, at the temperatures of $-1{ }^{\circ} \mathrm{C}, 21^{\circ} \mathrm{C}$ and $31^{\circ} \mathrm{C}$, no inflorescence initiation took place [23]. Temperatures of $20^{\circ} \mathrm{C}-30^{\circ} \mathrm{C}$ accelerated growth of emerged inflorescences compared with plants kept at $15^{\circ} \mathrm{C}$ $20^{\circ} \mathrm{C}$ [29]. Transfer of plants to $20^{\circ} \mathrm{C}-30^{\circ} \mathrm{C}$ after inflorescence emergence accelerated seed ripening by $4-5$ weeks compared with plants kept at $15^{\circ} \mathrm{C}$ to $20^{\circ} \mathrm{C}$ [29]. In over wintering plants in a glasshouse at $5^{\circ} \mathrm{C}$ to $10^{\circ} \mathrm{C}$ rather than outside lead to earlier flowering and seed ripening and larger seed yields [29]. The opening of florets occurred 11 days earlier at $22^{\circ} \mathrm{C}$ as compared to $16^{\circ} \mathrm{C}$ [30]. In other studies, it is reported that temperatures in the range of $10^{\circ} \mathrm{C}$ to $20^{\circ} \mathrm{C}$ favour the emergence of inflorescence following its initiation [22] [23] [29] [38] [50]. Inflorescence emergence was faster at $20^{\circ} \mathrm{C}$ than at $15^{\circ} \mathrm{C}$ [15]. High temperatures of $25^{\circ} \mathrm{C}-26^{\circ} \mathrm{C}$ [22] and $30^{\circ} \mathrm{C}$ [53] [54] were found to suppress the emergence of inflorescences already initiated. At high temperatures of $21^{\circ} \mathrm{C}$ $26.6^{\circ} \mathrm{C}$ almost no flower stalks emerged [22] [38] [50]. Emergence of seed stalk took place at $10^{\circ} \mathrm{C}-16^{\circ} \mathrm{C}$, but not at $21^{\circ} \mathrm{C}-27^{\circ} \mathrm{C}$ in the glasshouse [57]. Hot temperatures $\left(20^{\circ} \mathrm{C}-29^{\circ} \mathrm{C}\right)$ after planting of sets with well-developed inflorescence initials had a suppressing effect upon the emergence of the inflorescence [23]. High temperature $\left(28^{\circ} \mathrm{C}-30^{\circ} \mathrm{C}\right)$ during storage inhibits inflorescence initiation and prevents floral initiation [4]. Cultivars from the northern USSR had a temperature optimum of $3^{\circ} \mathrm{C}$ to $4^{\circ} \mathrm{C}$, whereas for those from the south it was $9^{\circ} \mathrm{C}$ to $10^{\circ} \mathrm{C}$ [65]. Thus cultivars seem to differ somewhat in their optimal temperature requirements depending on the locality to which they are adapted.

\subsection{Temperature and Photoperiod}

Photoperiod had no effect on the initiation of inflorescences [24] [50] [55]. Although long photoperiods did not have any effect on the percentage of sets producing inflorescences, it did hasten inflorescence development [38]. The rate of progress to flower initiation was more or less a linear function of photoperiod between $8-20 \mathrm{hd}^{-1}$ under inductive temperatures [19]. Other reports showed that extended photoperiods during vernalization promoted initiation [12] [57]. This was confirmed that, at an inductive temperature $\left(9^{\circ} \mathrm{C}\right)$, inflorescence initiation was accelerated by long photoperiods particularly for cv. "Rijnsburger" where the average time for initiation 
was 86 days in 8 hours and 38 days in 20 hours photoperiods [14]. Floral initiation was as rapid at $12^{\circ} \mathrm{C}$ as at $9^{\circ} \mathrm{C}$ but was slower at $6^{\circ} \mathrm{C}$ and $\mathrm{cv}$. "Senshyu" initiated more slowly than cv. "Rijnsburger" and was less sensitive to photoperiod [14]. Emergence of inflorescence was faster at $20^{\circ} \mathrm{C}$ and long days i.e. 14 hours compared to 8 hours [15]. Similarly, extending the day length from normal day to 15 hours, at a temperature of $10^{\circ} \mathrm{C}-16^{\circ} \mathrm{C}$, resulted in doubling of seed stalk height [57]. Once an inflorescence has been initiated, its rate of development increases with increases in temperature $\left(10^{\circ} \mathrm{C}-30^{\circ} \mathrm{C}\right)$ and lengthening of the photoperiod $\left(14-16 \mathrm{hd}^{-1}\right)$ [14] [15] [22] [29] [48] [57] [66]. However, high temperature (e.g., $30^{\circ} \mathrm{C}$ for cv. "Rijnsburger") during the very early development of the scape can result in flower abortion because of competition of assimilates from bulbing which may be induced if the day length is appropriate for the cultivar [24].

Plants grown under 8,12 and 16 hours photoperiods required 50 to 60 days of low temperature $\left(9^{\circ} \mathrm{C}\right)$ exposure for flower bud formation while those grown under 24 hours photoperiod required only 30 to 40 days exposure for floral initiation [12]. Some cultivars cannot initiate inflorescence or do so very slowly, under photoperiods shorter than 14 - 16 hours [14]. Under low temperatures, the time to floral initiation was hastened with lengthening photoperiods $\left(8 \mathrm{hd}^{-1}\right.$ to $\left.14 \mathrm{hd}^{-1}\right)$ [18]. It has been shown that inflorescences in most of cvs. ("Senshyu Yellow" "Delta” "Jaune Espagnol”, "Hygro", "Sito”, “Australian Brown”) initiated under short to intermediate day lengths $\left(8 \mathrm{hd}^{-1}, 11 \mathrm{hd}^{-1}\right.$ or $\left.14 \mathrm{hd}^{-1}\right)$ at temperatures from $11^{\circ} \mathrm{C}-13^{\circ} \mathrm{C}$ [18]. Inflorescence initiation in "Rijnsburger Balstora" took place under short photoperiod $\left(8 \mathrm{hd}^{-1}\right)$ at temperatures from $11^{\circ} \mathrm{C}$ to $13^{\circ} \mathrm{C}$ and under short to intermediate day lengths $\left(11 \mathrm{hd}^{-1}\right.$ and $\left.14 \mathrm{hd}^{-1}\right)$ from $11^{\circ} \mathrm{C}$ to $19^{\circ} \mathrm{C}$. "Phulkara" initiated inflorescences only under short day $\left(8 \mathrm{hd}^{-1}\right)$ at temperatures from $11^{\circ} \mathrm{C}$ to $13^{\circ} \mathrm{C}$ [18]. In another investigation, it was found that the time for development from inflorescence appearance to spathe opening was positively related to the mean temperature but also depended on mean day length $\times$ temperature [30]. It was confirmed that increasing mean temperatures $\left(14^{\circ} \mathrm{C}-23^{\circ} \mathrm{C}\right)$ and also day length $(11-17$ hours $)$ decreased the percentage of flowering shoots with already well developed inflorescence initials [67]. It was further shown that rate of progress towards spathe opening, flowering and seed ripening following inflorescence initiation, hastened in warmer temperature and also longer days and appeared to be a linear function of both photoperiod and temperature [67]. It was found that under short days (10 hours) flower stalks remained short and bore few flowers (florets) and the shortening of flower stalks was related to the delaying effect of short days on the emergence of the inflorescences [23]. A few studies regarding quantitative relationships of the effects of temperature and photoperiod on inflorescence appearance and subsequent development towards flowering reported that time to inflorescence appearance, scape elongation, spathe and floret opening decreased linearly as temperature and photoperiod increased [44]. At mild temperatures $\left(12.2^{\circ} \mathrm{C}-17.8^{\circ} \mathrm{C}\right)$, longer photoperiod enhanced florets per umbel, whereas at higher temperatures $\left(23^{\circ} \mathrm{C}-24.4^{\circ} \mathrm{C}\right)$, the floret number declined with lengthening photoperiods [44]. Studies have shown that inflorescence development in onion has several successive phases; each with different temperature requirements [24] and that day length as well as temperature can influence inflorescence development [44] [50]. Several authors have reported that inflorescence development subsequent to initiation is positively correlated with photoperiod [15] [24] [30] [50] [57] [68]. Long days at temperatures high enough to encourage rapid bulbing, suppressed inflorescence emergence and this was considered to be an indirect effect of long days due to the promotion of bulb development [48] [50] [54]. It was observed that, in plants with developed inflorescence initials kept in mild temperatures, long days (16 hours) accelerated scape elongation and caused considerable advancement in inflorescence emergence but tended to decrease the number of inflorescences emerging, resulting in a larger proportion of shoots forming bulbs rather than inflorescences [29]. Since high temperature promotes bulbing under long days [48] [69]-[70], high temperature can indirectly suppress inflorescence emergence. Such an indirect effect is different from the direct effect of high temperature in inhibition of inflorescence appearance [22]. It seems clear that high temperature alone is sufficient to prevent inflorescence emergence, when applied under short day conditions, in which bulbing does not occur [50]. However, the effects of temperature and day length on inflorescence emergence are complex and, under many conditions, can be disguised by the effects of these factors on bulbing.

In short days (10 hours), plants with developed inflorescence primordia emerge slowly if the temperature is mild [23] [48] [50] [54] but apart from the delaying effect of short days, at least in some cultivars, the number of plants with emerging inflorescence were increased [23]. However, in contrast, [68], in some cultivars short days (10 hours) can also reduce the number of emerged inflorescences to half compared to plants kept in long days (14 or 18 hours). It was reported that emergence of inflorescence was faster at high temperatures $\left(20^{\circ} \mathrm{C}-30^{\circ} \mathrm{C}\right)$ and long days (14 - 16 hours) [15] [29]. 
It was confirmed that emergence of inflorescences subsequent to their initiation was more rapid in 14 hours days than 8 hours days [15]. Long days accelerate the emergence of the flower stalk by increasing the rate of scape elongation [22] [48] [68]. Both warmer temperatures and long days accelerated inflorescence emergence in over-wintered and spring sown cultivars of onion [67]. It was found that number of florets per umbel was maximised under low temperatures $\left(12.4^{\circ} \mathrm{C}\right)$ and long days $17 \mathrm{hd}^{-1}[44]$.

\section{Bulb/Set Size and Storage Temperature}

It has been found that the initiation of inflorescences is favoured by large set or bulb size [9] [31] [38] [51] [53] [67] [71] or plant size [50]. Vernalization for 20 or 40 days at high altitude (3100 m.a.s.l) was insufficient to induce flowering but with 60 days vernalization, $18 \%$, $24 \%$ and $35 \%$ flowering was observed in the small, medium and large size bulbs of onion cv. "Texas Early Grano 502", respectively [34]. The stored bulbs of the cultivar "Texas Early Grano 502 PRR", at 3 localities viz. 1800, 2100 and 3100 m.a.s.l with average temperatures of $16.4^{\circ} \mathrm{C}, 14.5^{\circ} \mathrm{C}$ and $10.9^{\circ} \mathrm{C}$, respectively had $3 \%, 4.5 \%$ and $70 \%$ flowering, respectively [72]. Small sets (12.5 $\mathrm{mm}$ diameter) showed little or no bolting, and the percentage of bolting increased with increasing set-size (17.5 to $22.5 \mathrm{~mm}$ ) following linear relationship [9]. Sets of the spring-planted cultivar "Ailsa Craig”, 4 - $7 \mathrm{~g}$ in fresh weight (FW), initiated inflorescences, but those with a lower FW could not [56]. It was further observed that sets of spring-sown cv. "Ailsa Craig” of $4-7 \mathrm{~g}$ fresh weight were able to initiate inflorescences but those of a lower fresh weight could not, other than those between 2 - $4 \mathrm{~g}$ of which a few were able to initiate flowers [56] and that $4 \mathrm{~g}$ fresh weight might represent an approximate lower weight limit for inflorescence initiation in stored bulbs. It was observed that the larger the bulb weight, the shorter the period of low temperature $\left(9^{\circ} \mathrm{C}\right)$ exposure required for flower bud formation [13]. It was further reported that in variety "Senshuki" the critical bulb weight appeared to be about 100 - $150 \mathrm{~g}$ while in "Sapporoki" it appeared to be about 30 - $50 \mathrm{~g}$ [13]. Onion seedlings must be larger than a certain critical size before they can initiate inflorescences and for an autumn-sown cultivar this was about $0.45 \mathrm{~g}$ shoot dry weight [47].

Bulb size generally plays an important role in seed production. Bulb size influences the plant growth as well as seed yield [73]. The increase in number of leaves is directly related to the number of tillers. The more the number of tillers, the more were the leaves and vice versa [74]-[75]. Maximum plant height was recorded from large mother bulbs and earlier planting [76]-[78]. A larger mother bulb having a larger food supply and water content than the smaller bulbs enables the development of vigorous plants and production of higher seed yields [73] [79]-[83]. It has been reported that large sets initiated inflorescence sooner than small sets and time to floret opening decreased with increasing set-size [9] [23]. Bulb or set size affects umbel and seed number as well [40] [84]. It is generally accepted that large bulbs produce more flower stalks and give higher seed yield [9] [31] [78] [84]-[88]. Bulbs with $6.9 \mathrm{~cm}$ diameter produced higher number of flower stalks compared to those with $4.8 \mathrm{~cm}$ diameter [36]. Several workers [9] [31] [40] [85] [89] have reported a greater seed yield in large bulbs and attributed this to a larger amount of available assimilates in large bulbs. It was observed that the big bulbs gave larger number of seed stalks than medium and small ones [75] [82] [87] [90]-[93]. Moreover, the seed yield was higher for plants grown from large bulbs in comparison with the small ones [93] [94]. The length of scape increased with the increase in bulb size [95]. Moreover, the number of umbels was higher in large bulbs than small ones [91]. Large sized bulbs produced the highest umbel diameter followed by the medium size, while the smallest umbel was observed in the plants having smaller bulbs [81]. Higher seed yield has been reported from onion plants grown from bigger bulbs [94] [96]. Larger bulbs produced maximum flowers per umbel that were lowest in small bulbs [97]. The number of effective seeds per umbel increased with the increase in bulb size [83] [98]. There was a significant increase in 1000-seed weight with the increase in bulb size [91] [99]. The best seed stalk development resulted from bulbs stored at $5^{\circ} \mathrm{C}-10^{\circ} \mathrm{C}$ and that higher temperature reduced their development [38]. The number of seed stalks/plant and seed yield increased with increase in bulb size from 5 to $7 \mathrm{~cm}$ [100]. In growing seedlings also, a larger plant size has been found to favour inflorescence initiation [50] and study has been made to measure the minimum seedling size for initiation [42]. Low temperature storage at $0^{\circ} \mathrm{C}$ for 14 weeks reduced bolting appreciably in the case of the smaller sets [53] [56]. Several studies have shown that inflorescence primordia are initiated during storage of mother bulbs after sufficient accumulation of low temperatures between $5^{\circ} \mathrm{C}$ and $15^{\circ} \mathrm{C}$ [22]-[24] [31] [38] [48] [50].

Most studies on the effects of storage temperature on inflorescence initiation in onion have shown that the optimum temperature for flowering is in a range between $5^{\circ} \mathrm{C}$ to $13^{\circ} \mathrm{C}$ and is greatly reduced or suppressed at tem- 
peratures in the range of $15.5^{\circ} \mathrm{C}-30^{\circ} \mathrm{C}$ and low temperature of $-3^{\circ} \mathrm{C}$ to $0^{\circ} \mathrm{C}$ [13] [18] [44] [52] [53] [60] [66]. It has been reported that optimum storage duration for flower initiation of onion cultivars at low temperature $\left(3^{\circ} \mathrm{C}\right.$ $11^{\circ} \mathrm{C}$ ) is in the range of 7 to 90 days [15] [16] [25]. Onion sets treated for 90 days at $5^{\circ} \mathrm{C}$ produced seven times more bolters than those treated for 20 days and flowering did not occur in the sets kept for 10 days at low temperature [17]. The highest percentage of bolting was observed when onion sets were stored for the longest period of 90 days at $10^{\circ} \mathrm{C}$ followed by the shortest period of 10 days at $30^{\circ} \mathrm{C}$ or when stored at $10^{\circ} \mathrm{C}$ for 90 days [25]. The bolting was substantially increased by lower storage temperature of $5^{\circ} \mathrm{C}$ while higher temperatures $\left(25^{\circ} \mathrm{C}\right.$ or $\left.30^{\circ} \mathrm{C}\right)$ suppressed/delayed bolting and subsequent floret opening [31]. Experiments, in which cold treatments at different temperature levels were compared, showed a progressive decrease in flowering with increase in temperature [12] [24] [31] [38] [41] [45] [52]. Inflorescence initials were not observed in sets stored at $-1.1^{\circ} \mathrm{C}$ or at $15.5^{\circ} \mathrm{C}$ to $21.1^{\circ} \mathrm{C}$ but those stored at $0^{\circ} \mathrm{C}, 4.4^{\circ} \mathrm{C}$ and $10^{\circ} \mathrm{C}$ initiated inflorescence primordia [38]. Bulbs grown under $10^{\circ} \mathrm{C}$ to $15.5^{\circ} \mathrm{C}$ or stored at $10^{\circ} \mathrm{C}$ exhibited more inflorescence initials compared with those kept under lower $\left(0.1^{\circ} \mathrm{C}\right)$ or higher $\left(15.5^{\circ} \mathrm{C}\right.$ to $\left.21^{\circ} \mathrm{C}\right)$ temperatures [57]. The inflorescence initiation was favoured by temperatures cooler than $15^{\circ} \mathrm{C}$ and was prevented by both cold (about $0^{\circ} \mathrm{C}$ ) and warm (over $17^{\circ} \mathrm{C}$ ) temperatures [22] [48] [50]. Floral primordial formation was inhibited although not entirely prevented by storing the bulbs at low temperature of $0^{\circ} \mathrm{C}$ and storage at $-3^{\circ} \mathrm{C}$ and above $17^{\circ} \mathrm{C}$ resulted in a very low percentage of flowering plants [61]. Floral primordial formation was almost inhibited at $0^{\circ} \mathrm{C}$ and it was optimum at $5^{\circ} \mathrm{C}$ to $7^{\circ} \mathrm{C}$ [51]. The effect of very low temperature $\left(0^{\circ} \mathrm{C}\right)$ in inhibiting inflorescence initiation has been attributed to dormancy conditions and a low rate of development within the bulb [64]. The effect of low temperature was found to be cumulative, i.e., the longer the cold storage, the greater the inhibitory effect upon the floral primordial development [31] [51] [57]. Onion sets stored at $0^{\circ} \mathrm{C}$ for 6 to 8 months did not bolt as rapidly as sets at $4.4^{\circ} \mathrm{C}$ and $10^{\circ} \mathrm{C}$ [51]. Very low temperature $\left(0^{\circ} \mathrm{C}\right)$ and higher storage temperatures $\left(25^{\circ} \mathrm{C}\right.$ and $\left.30^{\circ} \mathrm{C}\right)$ for 120 days reduced bolting compared with 90 days storage while, storage temperatures of $5^{\circ} \mathrm{C}, 10^{\circ} \mathrm{C}, 15^{\circ} \mathrm{C}$ and $20^{\circ} \mathrm{C}$ for 120 days increased bolting compared with that of 90 days storage [31]. It was concluded that optimal temperatures for flower initiation were in the range of $5^{\circ} \mathrm{C}$ to $12^{\circ} \mathrm{C}$ [4] [43].

During storage, inflorescence development varies with temperature. Above the optimal range of $5^{\circ} \mathrm{C}$ to $12^{\circ} \mathrm{C}$ [23] [24] [51] [61], the initiated reproductive organs may be harmed or even, destroyed and below the optimal range floral development can be delayed. Storage of bulbs in the range of temperatures $5^{\circ} \mathrm{C}$ to $15^{\circ} \mathrm{C}$ stimulated subsequent inflorescence development while higher temperatures $\left(16^{\circ} \mathrm{C}\right.$ or above) reduced it [26] [57]. The reason for this may be that development of the inflorescence stops or is retarded by high temperature and only resumes after planting [23]. In large sets $(22.5 \mathrm{~mm})$ stored at $5^{\circ} \mathrm{C}$ for a period of 120 days, inflorescences emerged earlier, taking 48 days and 50 days for cultivars, "Hygro" and "Delta", respectively [31]. Sets stored at $4.4^{\circ} \mathrm{C}$ gave the largest percentage and the earliest development of seed stalks, followed by those kept at $10^{\circ} \mathrm{C}$ and $0^{\circ} \mathrm{C}$ [38]. Longer chilling treatments of sets at $5^{\circ} \mathrm{C}$ gave earlier inflorescence initiation, higher percentage of bolting, earlier spathe and floret opening, higher number of florets and seed yield per umbel compared to shorter treatments [17]. Time to inflorescence emergence in cultivars "Hygro" and "Delta", decreased significantly with increasing period of cool treatment at $5^{\circ} \mathrm{C}$ and floret opening occurred rapidly at low temperature $\left(5^{\circ} \mathrm{C}\right)$ treatment for 90 days, whilst it occurred more slowly after a short period exposure (20 days) at low temperature [17]. Inflorescence emergence occurred earlier in onion sets stored at $10^{\circ} \mathrm{C}$ for 90 days and floret opening occurred considerably earlier compared to sets which remained for longer period at higher temperature $\left(30^{\circ} \mathrm{C}\right)$ either before or after transfer [25]. The temperatures to which onion sets are subjected in storage have a great influence on seed yield. It has been reported that a $10^{\circ} \mathrm{C}, 20^{\circ} \mathrm{C}$ or "common" storage treatment resulted in significantly more florets per umbel than $0^{\circ} \mathrm{C}$ storage conditions [26]. Storage temperature is important for the development of florets within the spathe since this sometimes affects the number of florets per umbel [25] [26] [28]. For onion seed production most work has been concentrated on the use of bulbs and a little work appears to have been made to obtain a seed crop using sets [9] [17] [25] [31]. Storage of sets at $5^{\circ} \mathrm{C}$ gave maximum bolting and large sets produced higher seed yield [31]. Plants from bulbs stored for four months at $30^{\circ} \mathrm{C}$ developed a few seed stems and time of flowering was delayed considerably [52]. Bulbs stored between $7.5^{\circ} \mathrm{C}$ and $12^{\circ} \mathrm{C}$ produced plants that flowered earlier, had more seed stalks and a higher seed yield than did bulbs stored at $16^{\circ} \mathrm{C}$ or lower temperature $\left(3.5^{\circ} \mathrm{C}\right)$ [40] [52]. Onion plants from bulbs stored at $7^{\circ} \mathrm{C}$ the first half and $2^{\circ} \mathrm{C}$ the last half of the storage period had the highest seed yield and the greatest number of seeds/plant and the heaviest seeds were produced from bulbs that were stored at both $2^{\circ} \mathrm{C}$ and $7^{\circ} \mathrm{C}$ [27]. The number of florets per umbel increased progressively as the storage period of sets kept at $5^{\circ} \mathrm{C}$ increased up to 90 days and 90 days cold treatment produced the maximum 
percentage of seed bearing florets (70\% and 60\% for cultivars "Hygro" and "Delta", respectively), whilst the lowest (41\% and 34\%) was recorded after 20 days cold temperature treatment [17]. Moreover, there was a significant increase in the percentage of seed bearing florets per umbel where onion sets were kept at $10^{\circ} \mathrm{C}$ for 90 days as compared to those treated for shorter period [17]. It has also been found that cold treated bulbs yielded significantly more seed yield than GA3 and control [101].

\section{Genetic Variation}

Different cultivars are known to have different environmental optima, and require different lengths of time to pass through the stages in inflorescence initiation and development. The effects of temperature on floral initiation and its interaction with genotype and plant size were described in detail by several authors [11] [18] [19] [43] [50] [102]. Cultivars vary considerably in their susceptibility to bolting. Seed stalks emerged earlier in cultivars "Tarom" and "Yellow Sweet Spanish" than other landraces [100]. Cultivars adapted to warmer conditions have a smaller requirement for cold and possibly a higher optimum vernalization temperature. Certain cultivars (for example "Bawku") flowered at ambient night temperature of $15^{\circ} \mathrm{C}-21^{\circ} \mathrm{C}$ [37]. The response of European, Japanese, Turkish, Australian and Pakistani cultivars of onion to temperature and photoperiod showed that $11^{\circ} \mathrm{C}$ $13^{\circ} \mathrm{C}$ under photoperiod of 8,11 or $14 \mathrm{hd}^{-1}$ was optimal for flower induction in such cultivars [18]. Cultivar variation has been observed in response to storage temperature. The times required for inflorescence initiation were minimal and very similar, when seedlings were maintained at $9^{\circ} \mathrm{C}$ or $12^{\circ} \mathrm{C}$ for both an over wintered and a spring-sown cultivar, but more time was required at $6^{\circ} \mathrm{C}$ [14]. Cultivars selected for resistance to bolting require a longer cold stimulus at $9^{\circ} \mathrm{C}$ in comparison to normal spring sown cultivars [13]. Several varieties of onion induced inflorescences at $7^{\circ} \mathrm{C}-11^{\circ} \mathrm{C}$ for 45 to 60 days [16]. The optimum length of cold treatment at $8^{\circ} \mathrm{C}-10^{\circ} \mathrm{C}$ to obtain $>75 \%$ of bulbs flowering was 90 days [103]. It was shown that four weeks of chilling at $8^{\circ} \mathrm{C}$ was sufficient for floral initiation in "Gladalan Brown" and "Early Long Keeper" but the bolting-resistant cultivar, "Sakigake Yellow" required 8 weeks of chilling at $8^{\circ} \mathrm{C}$ [15]. Flowering of bolting resistant cultivars may be difficult and long treatment at low temperature or large bulb/set size may be required [13] [44]. Studies relating to floral initiation in two onion cultivars "Sturon" and "Stuttgarter" placed in a growth room at $12^{\circ} \mathrm{C}$, a light flux density of $120 \mu \mathrm{mol} \cdot \mathrm{m}^{-2} \cdot \mathrm{s}^{-1}$ and a 16-hour photoperiod showed that in $\mathrm{cv}$. "Stuttgarter", it took 195 days to initiate inflorescences, whereas time for initiation in cv. "Sturon" was 201 days [44]. The temperatures in the range of $7^{\circ} \mathrm{C}$ to $13^{\circ} \mathrm{C}$ were optimal for flower induction in European and Japanese cultivars [19]. Moreover, onion cultivars seem to differ in their optimal temperature requirements depending on the locality to which they are adapted. Bulbs stored at different temperatures showed that inflorescences in European and American cultivars are initiated most rapidly around $9^{\circ} \mathrm{C}$ to $12^{\circ} \mathrm{C}$, are slower to form at $4^{\circ} \mathrm{C}$ to $5^{\circ} \mathrm{C}$ and fail to form at $1^{\circ} \mathrm{C}$ or $17^{\circ} \mathrm{C}$ [22] [23] [41] [51]. But in tropical cultivars flowering was much better after bulb storage at $20^{\circ} \mathrm{C}$ than at $10^{\circ} \mathrm{C}$ [104]. A Nigerian cultivar, "Bawku" initiated flowers satisfactorily when ambient night temperatures were $15^{\circ} \mathrm{C}$ to $21^{\circ} \mathrm{C}$, a temperature range reported to be an upper limit for or even an inhibitor of flower induction [37]. In some tropical cultivars, flowering was improved after bulbs were stored at $20^{\circ} \mathrm{C}$ than at $10^{\circ} \mathrm{C}$ [104]. It was found that cultivars from the northern USSR required 60 days at $3^{\circ} \mathrm{C}-4^{\circ} \mathrm{C}$ to vernalize whereas cultivars from the southern USSR required 40 to 50 days at $9^{\circ} \mathrm{C}-10^{\circ} \mathrm{C}$ [65]. An abundance of flowering was reported for the short day cv. "Bawku" at ambient night temperature of $15^{\circ} \mathrm{C}$ to $21^{\circ} \mathrm{C}$ [37] [105]. Cultivars vary in their response to storage temperatures. The maximum temperature at which only a few or no plants initiated inflorescences was found to be $17^{\circ} \mathrm{C}$ for cvs. "Bedfordshire Champion", “Alisa Craig”, "Ebenezer", "Stock 28” and "Brown Globe" [50], above $17^{\circ} \mathrm{C}$ [61], $21^{\circ} \mathrm{C}$ [48] and $24^{\circ} \mathrm{C}$ [45] for other cultivars. It was found that storage at temperatures between $21^{\circ} \mathrm{C}$ to $27^{\circ} \mathrm{C}$ suppressed initiation of floral primordia for cvs. "Ebenezer" and "Sweet Spanish", [57] as did temperatures about $0^{\circ} \mathrm{C}$ [51]. In controlled temperature studies, depending on cultivars, the time to inflorescence initiation has been reported in the range of 20 - 90 days [12] [15] [16]. Cultivar "South Wester" was found to be more susceptible to bolting than other cultivars [106]. Significant differences were observed among the genotypes for days to $50 \%$ bolting, number of seed per umbel and seed yield per plant [107]. Cultivar "Sefid-e-Ghom" produced the highest seed yield than other landraces [100].

\section{Post-Planting Environmental Conditions}

The time of bulb planting had a significant effect on plant height [108]. Similarly, tallest plants were reported when mother bulbs were planted earlier (25 October) [78]. The post planting environmental conditions greatly 
affect bolting percentage of bulbs stored at an inductive temperature. The storage of bulbs for 30 days at $9^{\circ} \mathrm{C}$ and thereafter planting at two locations of Wageningen and Alkmaar in the Netherlands, gave 73\% and 84\% flowering plants, while for bulbs stored at temperature of $1^{\circ} \mathrm{C}$ for the same period of time, the respective figures were $10 \%$ and $66 \%$ [24]. These results indicate a strong environmental effect during the second growing season which might reduce the effects of cold storage. With an early sowing of cultivar 'South Wester', the percentage of bolters increased and as sowing date was delayed, the percentage of bolters decreased [106]. Time of flowering may be influenced by the temperature used for cold storage, and by the date of planting [3] [9] [11] [26]-[29]. Planting time had a marked influence on days to flowering [78] [109] [110]. The seedlings of cultivar "White Sweet Spanish" when transplanted on 6 September in California produced 71\% bolters, while the cultivar "Italian Red" produced no bolters [111] and seedlings of the cultivar "White Sweet Spanish", when transplanted two months later produced only $2.6 \%$ bolters. It was reported that in the late planting; the plants were still small when the flower-inducing temperature prevailed and the tendency to bolt was therefore, retarded [112]. Late planting of onion sets reduced the incidence of bolting presumably because the onset of bulbing suppressed flower emergence and bulbing occurred rapidly in the long day and high temperature conditions of summer [9] [45] [71]. It was found that the earliest planting date (5 December) gave the highest percentage of bolting in onion cultivars "Hygro" and "Delta", whereas all plantings thereafter showed progressively reduced bolting with the lowest at late planting of sets (5 March) [9]. It was also observed that time to inflorescence emergence in onion cultivars decreased linearly with increasing set-size and also with earlier planting date and in large sets, the inflorescences appeared rapidly from the earliest planting (5 December) compared with the last planting (5 March) [9]. It is further reported that earlier planting has a significant effect on the umbel diameter [113]. Different bulb sizes had significant effect on seed yield per plant which increased with increase in bulb size and planting time [83]. Maximum seed yield in onion has been reported from large mother bulbs and early planting time [88] [114] [115]. The highest seed yield has been reported from large mother bulbs with early planting while, the lowest seed yield from small mother bulbs with late planting [78] [116].

\section{Conclusion}

Cultivars vary considerably in their susceptibility to bolting. Cultivars adapted to warmer conditions have a smaller requirement for cold and possibly a higher optimum vernalization temperature. Cultivars selected for resistance to bolting require a longer cold stimulus at $9^{\circ} \mathrm{C}$ in comparison to normal spring sown cultivars. Different bulb sizes had significant effect on seed yield per plant which increased with increase in bulb size and planting time. The post planting environmental conditions greatly affect bolting percentage of bulbs stored at an inductive temperature. The rate of progress towards spathe opening, flowering and seed ripening following inflorescence initiation, is hastened at warmer temperatures and also longer days and appears to be a linear function of both photoperiod and temperature.

\section{References}

[1] Bassett, M.J. (1986) Breeding Vegetable Crops. AVI Publishing Co., USA, 584pp.

[2] FAO (2013) FAO Statistical Yearbook (2013) World Food and Agriculture Organization, Rome.

[3] Currah, L. (1981) Onion Flowering and Seed Production. Scientific Horticulture, 32, 26-46.

[4] Rabinowitch, H.D. (1990) Physiology of Flowering. In: Rabinowitch, H.D. and Brewster, J.L. (Eds.), Onions and Allied Crops. Botany, Physiology and Genetics, Vol. 1, CRC Press, Boca Raton, 133-134.

[5] Rabinowitch, H.D. (1990) Seed Development. In: Rabinowitch, H.D. and Brewster, J.L. (Eds.), Onions and Allied Crops. Botany, Physiology and Genetics, Vol. 1, CRC Press, Boca Raton, 151-159.

[6] Peters, R. (1990) Seed Production in Onions and Some Other Allium Species. In: Rabinowitch, H.D. and Brewster, J.L. (Eds.), Onions and Allied Crops. Botany, Physiology and Genetics, Vol. 1, CRC Press, Boca Raton, 161-176.

[7] Brewster, J.L. (1994) Onions and Other Vegetable Alliums. CAB International, Wallingford, 236.

[8] Lemma, D. and Shimeles, A. (2003) Research Experiences in Onion Production. Ethiopia Agricultural Research Organization. Research Report, No. 55.

[9] Khokhar, K.M. (2008) Effect of Set-Size and Planting Time on the Incidence of Bolting, Bulbing, and Seed Yield in Two Onion Cultivars. Journal of Horticultural Science and Biotechnology, 83, 481-487.

[10] Thomas, B. and Vince-Prue, D. (1997) Photoperiodism in Plants. Academic Press, San Diego. 
[11] Jones, H.A. and Mann, L.K. (1963) Onion and Their Allies. Leonard Hill, (Books) Ltd., London, 1-169.

[12] Shishido, Y. and Saito, T. (1975) Studies on the Flower Bud Formation in Onion Plants. 1. Effects of Temperature, Photoperiod and Light Intensity on the Low Temperature Induction of Flower Buds. Journal of Japanese Society for Horticultural Science, 44, 122-130. (In Japanese) http://dx.doi.org/10.2503/jjshs.44.122

[13] Shishido, Y. and Saito, T. (1977) Studies on the Flower Bud Formation in Onion Plants. III. Effects of Physiological Conditions on the Low Temperature Induction of Flower Buds in Bulbs. Journal of Japanese Society for Horticultural Science, 46, 310-316. (In Japanese) http://dx.doi.org/10.2503/jjshs.46.310

[14] Brewster, J.L. (1983) Effects of Photoperiod, Nitrogen Nutrition and Temperature on Inflorescence Initiation and Development in Onion (Allium cepa L.). Annals of Botany, 51, 429-440.

[15] Bertaud, D.S. (1988) Effects of Chilling Duration, Photoperiod and Temperature on Floral Initiation and Development in Sprouted and Unsprouted Onion Bulbs. Proceeding of the 4th EUCARPIA Allium Symposium, Wellesbourne, 6-9 September 1988, 254-261.

[16] DeBon, H. and Rhino, B. (1988) Flowering in the Various Cultivars of Onions (Allium cepa L.) Brought to Martinique (French West Indies). Proceeding of the 4th EUCARPIA Allium Symposium, Wellesbourne, 6-9 September 1988, 262266.

[17] Khokhar, K.M., Hadley, P. and Pearson, S. (2007) Effect of Cold Temperature Durations of Onion Sets in Store on the Incidence of Bolting, Bulbing and Seed Yield. Scientia Horticulturae, 112, 16-22. http://dx.doi.org/10.1016/j.scienta.2006.12.038

[18] Khokhar, K.M. (2008) Effect of Temperature and Photoperiod on the Incidence of Bulbing and Bolting in Seedlings of Onion Cultivars of Diverse Origin. Journal of Horticultural Science and Biotechnology, 83, 488-496.

[19] Brewster, J.L. (1987) Vernalization in the Onion-A Quantitative Approach. In: Etherton, J.G., Ed., Manipulation of Flowering, Butterworths, London, 171-183. http://dx.doi.org/10.1016/B978-0-407-00570-9.50018-1

[20] Kimani, P.M., Kariuki, J.L.W., Peters, R. and Rabinowitch, H.D. (1994) Potential of Onion Seed Production in a Tropical Environment. Acta Horticulturae, 358, 341-348.

[21] Currah, L. and Proctor, F.J. (1990) Onions in Tropical Regions. Natural Resources Institute Bulletin, 35.

[22] Heath, O.V.S. and Mathur, P.B. (1944) Studies in the Physiology of the Onion Plant. II. Inflorescence Initiation and Development, and Other Changes in the Internal Morphology of Onion Sets, as Influenced by Temperature and Day Length. Annals of Applied Biology, 31, 173-187. http://dx.doi.org/10.1111/j.1744-7348.1944.tb06724.x

[23] Aura, K. (1963) Studies on the Vegetatively Propagated Onions Cultivated in Finland, with Special Reference to Flowering and Storage. Annales Agriculturae Fenniae, 2, 1-74.

[24] Van Kampen, J. (1970) Shortening the Breeding Cycle in Onions. Journal Meded Proefstat Groent, 51. (In Dutch)

[25] Khokhar, K.M., Hadley, P. and Pearson, S. (2007) Effect of Reciprocal Transfers of Onion Sets between Inductive and Non-Inductive Temperatures on the Incidence of Bolting and Bulbing and Seed Yield. Scientia Horticulturae, 112, 245-250. http://dx.doi.org/10.1016/j.scienta.2006.12.034

[26] Atkin, J.D. and Davis, G.N. (1954) Altering Onion Flowering Dates to Facilitate Hybrid Seed Production. California Agricultural Experiment Station Bulletin.

[27] DeMille, B. and Vest, G. (1976) The Effect of Temperature and Light during Bulb Storage on Traits Related to Onion Seed Production. Journal of American Society for Horticultural Science, 52-53.

[28] Hesse, P.S., Vest, G. and Honma, S. (1979) The Effect of 4 Storage Treatments on Seed Yield Components of 3 Onion Inbreds. Scientia Horticulturae, 11, 207-215. http://dx.doi.org/10.1016/0304-4238(79)90001-3

[29] Brewster, J.L. (1982) Flowering and Seed Production in Overwintered Cultivars of Bulb Onions. Effects of Different Raising Environments, Temperatures and Day Lengths. Journal of Horticulture Science, 57, 93-101.

[30] Brewster, J.L. (1982) Flowering and Seed Production in Overwintered Cultivars of Bulb Onions. Quantitative Relationships between Mean Temperatures and Day Lengths and the Rate of Inflorescence Development. Journal of Horticulture Science, 57, 103-108.

[31] Khokhar, K.M. (2009) Effect of Set-Size and Storage Temperature on the Incidence of Bolting, Bulbing, and Seed Yield in Two Onion Cultivars. Scientia Horticulturae, 122, 187-194. http://dx.doi.org/10.1016/j.scienta.2009.05.008

[32] Ami, E.J., Islam, M.T. and Farooque, A.M. (2013) Effect of Vernalization on Seed Production of Onion. Agriculture, Forestry and Fisheries, 2, 212-217. http://dx.doi.org/10.11648/j.aff.20130206.12

[33] Behairy, A.G. and Habbasha, K.M.E. (1979) Onion (Allium cepa L.) Seed Production as Affected by Vernalization of Bulbs.

[34] Ramos, D.S.G. and Ramos, A.A. (1994) Effect of Three Lengths of Vernalization on the Flowering of Onion Mother Bulbs of Three Weight Classes. Onion Newsletter for the Tropics, Venezuela, 6, 48-51. 
[35] Msika, R.L., Jackson, J.E. and Currah, L. (1997) Onion Seed Production Trials in the Highveld of Zimbabwe. ActaHorticulturae, 433, 337-346.

[36] Reghin, M.Y., Otto, R.F., Olinik, J.R., Jacoby, C.F.S. and de Oliveira, R.P. (2005) Vernalization of Bulbs and the Effect on Yield and Physiological Potential of Onion Seeds. Horticultura Brasileira, 23, 294-298. http://dx.doi.org/10.1590/S0102-05362005000200026

[37] Sinnadurai, S. (1970) A Note on the Bulbing and Flowering Habit of the Bawku Onion. Tropical Agriculture (Trinidad), 47, 77-79.

[38] Thompson, H.C. and Smith, O. (1938) Seedstalk and Bulb Development in the Onion (Allium cepa L.). Cornell University Agricultural Experiment Station Bulletin.

[39] Roberts, R.H. and Struckmeyer, B.E. (1951) Observations on the Flowering of Onions. Proceedings of American Society for Horticultural Science, 58, 213-216.

[40] Jones, H.A. and Emsweller, S.L. (1939) Effect of Storage, Bulb Size, Spacing and Time of Planting on Production of Onion Seed. California Agricultural Experiment Station Bulletin.

[41] Hartsema, A.M. (1947) The Periodical Development of the Onion (Allium cepa L.), var. Giant Zittau. Mededeling Landbouwhogeschool Wageningen, 48, 265-300. (In Dutch)

[42] Shishido, Y. and Saito, T. (1976) Studies on the Flower Bud Formation in Onion Plants. 11. Effects of Physiological Conditions on the Low Temperature Induction of Flower Buds on Green Plants. Journal of Japanese Society for Horticultural Science, 45, 160-167. (In Japanese) http://dx.doi.org/10.2503/jijshs.45.160

[43] Rabinowitch, H.D. (1985) Onions and Other Edible Alliums. In: Halevy, A.H., Ed., Handbook of Flowering, Vol. 1, CRC Press, Boca Raton, 398-405.

[44] Khokhar, K.M., Hadley, P. and Pearson, S. (2007) Effect of Photoperiod and Temperature on Inflorescence Appearance and Subsequent Development towards Flowering in Onion Raised from Sets. Scientia Horticulturae, 112, 9-15. http://dx.doi.org/10.1016/j.scienta.2006.12.009

[45] Heath, O.V.S. and Holdsworth, M. (1948) Morphogenic Factors as Exemplified by the Onion Plant. In: Daneellie, J.F. and Brown, R., Eds., Growth in Relation to Differentiation and Morphogenesis, Cambridge University Press, Cambridge, 326-350.

[46] Ito, K. (1956) Studies on the Bolting of Onion. I. Relation between the Flower Bud Formation and the Bulb Division. Journal of Japanese Society for Horticultural Science, 25, 187-193. (In Japanese) http://dx.doi.org/10.2503/jjshs.25.187

[47] Brewster, J.L. (1985) The Influence of Seedling Size and Carbohydrate Status and Photon Flux Density during Vernalization on Inflorescence Initiation in Onion (Allium cepa L). Annals of Botany, 55, 403-414.

[48] Heath, O.V.S. (1945) Formative Effects of Environmental Factors as Exemplified in the Development of the Onion Plant. Nature, 155, 623-626.

[49] Szalay, F. (1974) Correlations between the Winter Storage Temperature and Seed Stalk Formation in the Onion Cultivar Makoi. Kiserletugyi Kozlemenyek, 66, 23-34. (In Hungarian)

[50] Holdsworth, M. and Heath, O.V.S. (1950) Studies in the Physiology of the Onion Plant. Journal of Experimental Botany, 1, 353-375. http://dx.doi.org/10.1093/jxb/1.3.353

[51] Boswell, V.R. (1923) Influence of Time of Maturity of Onions on the Behaviour during Storage and the Effect of Storage Temperature on Subsequent Vegetative and Reproductive Development. Proceedings of American Society for Horticultural Science, 20, 234-239.

[52] Jones, H.A. (1927) The Influence of Storage Temperature on Seed Production in the Ebenezer Onion. Proceedings of American Society for Horticultural Science, 24, 61-63.

[53] Heath, O.V.S. (1943) Studies in the Physiology of the Onion Plant. I. An Investigation of Factors Concerned in the Flowering ("Bolting”) of Onions Grown from Sets and Its Prevention. Annals of Applied Biology, 30, 208-220. http://dx.doi.org/10.1111/j.1744-7348.1943.tb06706.x

[54] Heath, O.V.S. (1943) Studies in the Physiology of the Onion Plant. I. An Investigation of Factors Concerned in the Flowering ("Bolting”) of Onions Grown from Sets and Its Prevention. Annals of Applied Biology, 30, 308-322. http://dx.doi.org/10.1111/j.1744-7348.1943.tb06706.x

[55] Heath, O.V.S. and Holdsworth, M. (1943) Bulb Formation and Flower Production in Onion Plants Grown from Sets. Nature, 152, 334-335.

[56] Heath, O.V.S., Holdsworth, M., Tincker, M.A.H. and Brown, F.C. (1947) Studies in the Physiology of the Onion Plant. III. Further Experiments on the Effects of Storage Temperature and Other Factors on Onions Grown from Sets. Annals of Applied Biology, 34, 473-502. http://dx.doi.org/10.1111/j.1744-7348.1947.tb06383.x

[57] Woodbury, G.W. (1950) A Study of Factors Influencing Floral Initiation and Seedstalk Development in the Onion, Al- 
lium cepa Linn. Idaho Agricultural Experiment Station Research Bulletin, 18, 27.

[58] Lachman, W.H. and Upham, E.E. (1954) Effect of Warm Storage on the Bolting of Onions Grown from Sets, (a Preliminary Report). Proceedings of American Society for Horticultural Science, 63, 342-346.

[59] Manczak, M. (1959) The Influence of Size of Onion Sets and Storage Temperature on Seed Stalks Development and Yields in Various Onion Varieties. Biuletyn Warzywniczy, 4, 175-190.

[60] Lachman, W.H. and Michelson, L.F. (1960) Effects of Warm Storage on the Bolting of Onion Grown from Sets. Proceedings of American Society for Horticultural Science, 75, 495-499.

[61] Woyke, H. and Manczak, M. (1965) Number of Seed-Stalks and the Seed Yield of Several Bred and Local Onion Varieties as Affected by the Temperature at which the Bulbs had been Stored. Biuletyn Warzywniczy, 8, 239-262. (In Polish)

[62] Aura, K. (1968) Studies on the Vegetatively Propagated Onions Cultivated in Finnland, with Special Reference to Flowering and Storage. IX. The Influence of Various Storae Temperatures on Flowering and Yield in the North Finnish Onion Strain. Annales Agriculturae Fenniae, 7, 183-188.

[63] DeMille, B. and Vest, G. (1975) Flowering Date of Onion Bulbs as Affected by Light and Temperature Treatments during Storage. Journal of American Society for Horticultural Science, 100, 423-424.

[64] Brewster, J.L. (1977) The Physiology of the Onion. Horticultural Abstracts, 47(1), 17-23, and 47(2), 103-112.

[65] Kruzhilin, A.S. and Shvedskaya, Z.M. (1962) Peculiarities of Phasic Development and Morphogenesis in Onion (Allium cepa). Fiziologia Rastenii, 9, 466-475.

[66] Brewster, J.L. (1987) The Effect of Temperature on the Rate of Sprout Growth and Development within Stored Onion Bulbs. Annals of Applied Biology, 111, 463-467. http://dx.doi.org/10.1111/j.1744-7348.1987.tb01475.x

[67] Mobli, M. (1992) Quantitative Effects of Bulb Size, Pre- and Post-Planting Environment on Flowering and Seed Production in Onion, Allium cepa L. Ph.D. Thesis, University of Reading, Reading.

[68] Scully, N.J., Parker, M.W. and Borthwick, H.A. (1945) Interaction of Nitrogen Nutrition and Photoperiod as Expressed in Bulbing and Flower-Stalk Development of Onion. Botanical Gazette, 107, 52-61. http://dx.doi.org/10.1086/335327

[69] Kato, T. (1964) Physiological Studies on Bulb Formation and Dormancy in Onion Plant. III. Effects of External Factors on the Bulb Formation and Development. Journal of Japanese Society for Horticultural Science, 33, 53-61. (In Japanese) http://dx.doi.org/10.2503/jishs.33.53

[70] Steer, B.T. (1980) The Bulbing Response to Day-Length and Temperature of Some Australian Cultivars of Onion (Allium cepa L.). Australian Journal of Agricultural Research, 31, 511-518. http://dx.doi.org/10.1071/AR9800511

[71] Holdsworth, M. (1945) A Comparative Study of Onion Varieties in Relation to Bolting and Yield when Grown from Sets. Annals of Applied Biology, 32, 22-34. http://dx.doi.org/10.1111/j.1744-7348.1945.tb06754.x

[72] Diaz, T.R. and Leon, B. (1994) Effect of Temperature at Different Bioclimatic Levels on Vernalization of Onion, Allium cepa L., Mother Plants. Agronomia Tropical Maracay, 44, 743-751.

[73] Baloch, M.A., Hussain, S.A. and Ali, N. (1998) Study on the Effects of Planting Space and Bulb Size on Seed Production in Onion Crop. Sarhad Journal of Agriculture, 14, 563-568.

[74] Singh, S.R. and Sachan, B.P. (1999) Interaction of Bulb Size and Spacing on Seed Yield and Yield Attributing Trait of Onion (Allium cepa L.) cv. Kalyanpur Round Red. Scientific Horticulture, 6, 125-128.

[75] Hussain, S.W., Ishtiaq, M. and Hussain, S.A. (2001) Effect of Different Bulb Size and Planting Dates on Green Leaf Production of Onion (Allium cepa L.). Journal of Biological Sciences, 1, 345-347. http://dx.doi.org/10.3923/jbs.2001.345.347

[76] Khan, M.A., Hassan, M.K., Ara, R., Alam, M.M. and Brahma, S. (2005) Effect of Bulb Size and Harvesting Time on the Growth and Yield of Onion. Progressive Agriculture, 16, 25-29.

[77] Khodadadi, M. and Hassanpanah, D. (2012) The Effects of Planting Date and Mother Bulb Size on Quantitative and Qualitative Seed Traits of Onion Red Rey Variety. International Journal of Agricultural Research and Review, 2, 324327.

[78] Ashagrie, T., Belew, D., Alamerew, S. and Getachew, Y. (2014) Effects of Planting Time and Mother Bulb Size on Onion (Allium cepa L.) Seed Yield and Quality at Kobo Woreda, Northern Ethiopia. International Journal of Agricultural Research, 1-11.

[79] Levy, D., Ben-Herut, Z., Albasel, N., Kaisi, F. and Manasra, I. (1981) Growing Onion Seeds in an Arid Region; Drought Tolerance and the Effect of Bulb Weight, Spacing and Fertilization. Scientia Horticulturae, 14, 1-7. http://dx.doi.org/10.1016/0304-4238(81)90072-8

[80] Verma, T.S., Chand, R., Thakur, P.C., Lalkhanpal, K.D. and Singh, A. (1994) Effect of Bulb Size and Plant Spacing on Yield of Onion. Indian Journal of Hill Farming, 7, 102-104. 
[81] Ambulker, M.R., Kale, P.B., Gonge, V.S. and Mahorkar, V.K. (1995) Effect of Bulb Size and Spacing on the Yield and Quality of Onion Seed (Allium cepa L.). PKV Research Journal, 19, 107-109.

[82] Abedin, M.J., Rahim, M.A., Islam, K.S. and Haider, M.A. (1999) Effect of Planting Date and Bulb Size on the Yield and Quality of Onion Seed. Bangladesh Journal of Seed Science Technology, 3, 25-28.

[83] Muktadir, M.S., Farooque, A.M., Rahim, M.A. and Hossain, M.M. (2001) Yield and Quality of Onion Seed as Influenced by the Planting Time and Bulb Size. Bangladesh Journal of Seed Science Technology, 5, 47-52.

[84] Orlowski, M. (1974) The Influence of Onion Bulb Sizes and Their Planting Density on the Quantity and Quality of the Seed Crop with Consideration of Economical Effects. Proceedings of the 19th International Horticultural Congress, 633.

[85] Chiru, C.R. and Banita, I. (1980) Experience of the Buzau Vegetable Research and Production Station Romania in Onion Seed Production. Productia Vegetala Horticultura, 29, 9-12. (In Romanes)

[86] Nourai, A.H. (1981) Effect of Bulb Size and In-Row Spacing on Onion Seed Yield. Hudeiba Research Station Annual Reports, 1.

[87] McDonald, M.B. and Copeland, L.O. (1997) Seed Production: Principles and Practices. Chapman and Hall, New York, p. 749.

[88] Asaduzzaman, M., Hasan, M. and Moniruzzaman, M. (2012) Quality Seed production of Onion (Allium cepa L.): An Integrated Approach of Bulb Size and Plant Spacing. Journal of Agricultural Research, 50, 119-128.

[89] Mishra, H.P. (1986) Effect of Time of Planting and Size of Mother Bulbs on Onion Seed Production. Indian Journal of Horticulture, 43, 140-143.

[90] George, R.A.T. (1985) Vegetable Seed Production. Longan Group Ltd.

[91] Singh, S.R. and Sachan, B.P. (1998) Response of Different Bulb Sizes and Varieties on Onion Allium cepa L. Seed Yield and Yield Attributing Trait. Crops Research Hisar, 15, 57-60.

[92] Khokhar, K.M., Hussain, S.I., Mahmood, T. and Bhatti, M.H. (2001) Effect of Set Size on Bulb Yield, Maturity and Bolting in Local and Exotic Cultivars of Onion during Autumn Season. Sarhad Journal of Agriculture, 17, 355-358.

[93] Morozowska, M. and Holubowicz, R. (2009) Effect of Bulb Size on Selected Morphological Characteristics of Seed Stalks, Seed Yield and Quality of onion (Allium cepa L.) Seeds. Folia Horticulturae, 21, 27-38. http://dx.doi.org/10.2478/fhort-2013-0123

[94] Aminpour, R. and Mortazavibak, A. (2004) Mother Bulb Size and Planting Pattern Effects on Seed Quality and Quantity of Onion (Allium cepa L.) Cv. Texas Early Grano 502. Seed Plant, 20, 39-48.

[95] Farag, I.A. and Koriem, S.O. (1996) Influence of Size and Cutting Mother Bulbs on Yield and Quality of Onion Seeds. Assiut Journal of Agricultural Sciences, 27, 97-106.

[96] Asaduzzaman, M., Hasan, M., Moniruzzaman, M. and Howlander, M.H.K. (2012) Effect of Bulb Size and Plant Spacing on Seed Production of Onion (Allium cepa L.). Bangladesh Journal of Agricultural Research, 37, 405-414. http://dx.doi.org/10.3329/bjar.v37i3.12084

[97] Rathore, S.V.S., Verma, J.P. and Kashap, V.S. (1975) Effect of Size of Bulb and Planting Distance on the Performance of Seed Crop of Onion. Bangladesh Horticulture, 8, 17-21.

[98] Begum, A., Rahim, M.A. and Haider, M.A. (1998) Effect of Set Size and Spacing on the Seed Harvesting Time, Growth and Yield of Onion. Progressive Agricultue, 16, 25-29.

[99] Ali, M., Quadir, M.A., Choudhury, A.R. and Alam, M.Z. (1998) Effect of Positive Selection of Mother Bulbs on Seed and Bulb Yield of Onion. Bangladesh Journal of Agriculture, 14, 57-63.

[100] Rafieipour, M., Motallebi-Azar, A., Mahna, N., Kazemnia, H., Kazemiani, S. and Yarmohamadi, F. (2011) Evaluation of Genetic Variability of Six Iranian Landraces of Onion (Allium cepa L.) for Seed Yield and Yield Components. Russian Agricultural Sciences, 37, 385-391. http://dx.doi.org/10.3103/S1068367411050181

[101] Islam, M.R., Islam, M.M. and Kabir, M.Y. (2013) Performence of Cold and GA3 on Growth and Seed Yield of Onion. Annals of Biological Research, 4, 18-21.

[102] Hartsema, A.M. (1961) Influence of Temperature on Flower Formation and Flowering of Bulbous and Tuberous Plants. Allium cepa, Onion. Encyclopedia of Plant Physiology, 16, 147-150.

[103] Aguiar, P.A.A. (1984) Periodo de vernalizacao dos bulbos de cebolaparaproducao de sementes, no nordeste do Brasil. Pesquisa Agropecuaria Brasileira, 19, 197-200.

[104] Uzo, J.O. (1983) Induction of Biennial Reproductive Development in Short Day Onion Cultivars in a Low Latitude Tropical Environment. Gartenbauwissenschaft, 48, 149-153.

[105] Sinnadurai, S. (1970) The Effect of Light and Temperature on Onions. Ghana Journal of Agricultural Science, 3, 1315. 
[106] Bosekeng, G. and Coetzer, G.M. (2013) Response of Onion (Allium cepa L.) to Sowing Dates. African Journal of Agricultural Research, 8, 2757-2764.

[107] Islam, A.K.M.A., Sultana, M., Yeasmin, S. and Islam, A.K.M.M. (2011) Screening of Local and Exotic Onion Cultivars for Seed Production Productivity. Poljoprivreda, 17, 52-57.

[108] Malik, Y.S., Singh, N. and Nehra, B.K. (1999) Effect of Planting Time, Bulb Cut and Pinching of Bolt Treatments on Yield and Quality of Onion Seed. Vegetable Science, 26, 143-145.

[109] Anisuzzaman, M., Ashrafuzzaman, M., Ismail, M.R., Uddin, M.K. and Rahman, M.A. (2009) Planting Time and Mulching Effect on Onion Development and Seed Production. African Journal of Biotechnology, 8, 412-416.

[110] Vianney, M.T.W., Albert, R. and Zoumbiesse, T. (2011) Effects of Seasons of Bulb and Seed Production on the Early Bolting of Onion (Allium cepa L.) cv. Violet de Galmi. Journal of Applied Biosciences, 40, 2652-2658.

[111] Davis, G.N. and Jones, H.A. (1944) Experiments with the Transplant Onion Crop in California. California Agricultural Experiment Station Bulletin, 682, 20.

[112] Lawadale, K.E. and Kale, P.N. (1986) Effect of Monthly Planting Round the Year on Yield, Bolting, Self-Topping and Twin Bulb Formation in Onions. Journal of Maharashtra Agricultural Universities, 11, 167-170.

[113] Patil, J.G., Shelar, V.R. and Shinde, S.K. (1993) Effect of Irrigation Intensity on Seed Yield and Components of Seed in Onion Seed Crop in India. Onion Newsletter for the Tropics, 4, 40-42.

[114] El-Aweel, M.A.T. and Ghobashi, A.A. (1999) Seed Production in Onion as Influenced by Dates of Planting in the Sultanate of Oman. Assiut Journal of Agricultural Sciences, 30, 43-53.

[115] El-Helaly, M.A. and Karam, S.S. (2012) Influence of Planting Date on the Production and Quality of Onion Seeds. Journal of Horticulture Science, 4, 275-279.

[116] Ud-Deen, M.M. (2008) Effect of Mother Bulb Size and Planting Time on Growth, Bulb and Seed Yield of Onion. Bangladesh Journal of Agricultural Research, 33, 531-537. 